\title{
AIRBORNE FUNGI IN THE REGION OF CUBATÃo, SÃO PAULO STATE, BRAZIL
}

\author{
Iracema H. Schoenlein-Crusius*; Sandra F.B. Trufem; Rosely A.P. Grandi; \\ Adauto I. Milanez; Carmen L.A. Pires-Zottarelli \\ Seção de Micologia e Liquenologia, Instituto de Botânica, São Paulo, SP, Brasil \\ Submitted: June 26, 2000; Returned to authors for corrections: September 14, 2000; Approved: February 01, 2001
}

\begin{abstract}
From March/1993 to March/1995, airborne fungi were isolated from the "Vale do Rio Moji" (highly affected by the air pollution caused by fertilizer industries, steel works, cement factories and chemical products industries, among others) and from the "Vale do Rio Pilões" (less affected by the air pollution), both in the municipality of Cubatão, São Paulo State, Brazil, by exposing Petri dishes with potato dextrose agar medium, placed one meter from the ground, during $5 \mathrm{~min}$. After 5 days of incubation at $20^{\circ} \mathrm{C}$, the colonies of the fungi were purified and identified, resulting in the identification of 39 taxa, three unidentified strains of Fusarium and non-sporulating cultures. A total of 28 taxa, one unidentified strain of Fusarium and non-sporulating fungi (71 records) were isolated in the "Vale do Rio Moji" and 29 taxa, two unidentified strains of Fusarium and non-sporulating fungi (72 records) in the "Vale do Rio Pilões. The airborne mycota of the higher polluted site presented 17 common, 12 rare and only one constant fungal species. In the other site, the airborne mycota was composed by 19 common, 10 rare and two constant fungal species. Among the obtained fungi, at least 12 taxa were reported as opportunistic fungi, 26 have been mentioned related to plant diseases and eight have been associated to allergy problems. The similarity Index of Sörensen between the mycotas, corresponding to 58\%, may be considered low, and is probably justified by the air pollution, that mainly distinguish the two studied areas.
\end{abstract}

Key words: fungal diversity, airborne fungi, Atlantic rainforest, air pollution

\section{INTRODUCTION}

The expansion of the knowledge about the diversity of airborne fungi, besides increasing concern about potential allergenic microorganisms, and the search for new indicators of environmental pollution have been the main reasons for the existence of several studies airborne fungi in Brazil $(3,4,9,10,11,22)$. Environmental parameters such as atmospheric pressure, wind, temperature and humidity may influence the concentration of fungal spores in the air or the diversity of airborne mycota $(9,11)$. Besides this, daily periodicity may be taken into account in order to understand the dispersion pattern of airborne fungi (12).

Comparisons of the predominance of certain genera in the air of towns and regions have often been reported $(8,10)$.
Responses of the fungal community to seasonal changes were verified in the city of São Paulo, where the number of genera such as Cladosporium, Epicoccum, Rhodotorula, Penicillium, Aspergillus, Aureobasidium, Phoma, Alternaria, Candida, Fusarium, Trichoderma, and Cephalosporium was higher in the autumn and winter (10). However, in smaller cities, such as Presidente Prudente (west of the São Paulo State), higher fungal frequencies were observed in spring and lower in autumn (4).

The frequency of airborne fungi was measured in several sites of the "Baixada Santista", São Paulo State, and correlated to certain geographic parameters, including a few related to environmental pollution. The less polluted region revealed a lower number of genera and fungal colonies. The use of the relative frequency of non-sporulating fungi as a microbiological indicator of atmospheric pollution was suggested (22). To confirm this

\footnotetext{
* Corresponding author. Mailing address: Seção de Micologia e Liquenologia, Instituto de Botânica, Av. Miguel Estéfano, 3687, CEP 04301-902, São Paulo, SP, Brasil E-mail: iracema@crusius.com.br
} 
hypothesis, cumulative results about the diversity of airborne fungi studied in extreme conditions of air pollution might be necessary. At the "Vale do Rio Moji" the strong influence of local pollutants has been shown in the diurnal variation of particulate matter and gases, such as sulfur dioxide $\left(\mathrm{SO}_{2}\right)$, nitrogen oxides $\left(\mathrm{NO}_{\mathrm{x}}\right)$, and ozone $\left(\mathrm{O}_{3}\right)$ concentrations (13).

In order to contribute to the knowledge of diversity under such conditions, a study was undertaken in the region of Cubatão (São Paulo State), comparing the diversity of mycota present in the air of a highly polluted site ("Vale do Rio Moji") with that of a less affected area ("Vale do Rio Pilões").

\section{MATERIALS AND METHODS}

The sites chosen are from the municipality of Cubatão, São

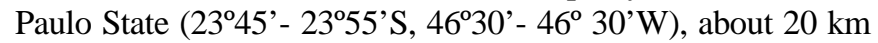
apart from each other (6). The area of the "Vale do Rio Moji" and "Vale do Rio Pilões" are located at similar altitudes (20 to $150 \mathrm{~m}$ ) and are under the same meteorological conditions (temperature around to $22^{\circ} \mathrm{C}$, humidity of $80 \%$ and about $2.500 \mathrm{~mm}$ of annual rainfalls), being submitted to different influence of the air pollution $(6,14)$.

The "Vale do Rio Moji" is an area downwind the industries of the Cubatão complex (6). The pollution in this area is caused by fertilizer industries, steel works and chemical products industries, increasing the amount of particulate matter, fluorides and compounds of nitrogen and sulfur (14), damaging severely the vegetation (15). Results of several monitoring experiments included in an agreement between the Brazilian and German Government indicate that, during the years of 1991 to 1995 , the concentration of nitrogen oxides, sulfur dioxide and ozone corresponded respectively to $26.2 \mu \mathrm{g} / \mathrm{m}^{3}, 30.2 \mu \mathrm{g} / \mathrm{m}^{3}$ and 29.4 $\mu \mathrm{g} / \mathrm{m}^{3}(6)$, classifying the area as highly affected by the air pollution of the industrial complex of Cubatão.

The area of the "Vale do Rio Pilões" has been studied as a reference site, showing apparently undamaged rainforest vegetation (15). The air pollution is considered low, with concentrations of nitrogen oxides, sulfur oxide and ozone respectively corresponding to $7.6 \mu \mathrm{g} / \mathrm{m}^{3}, 5.4 \mu \mathrm{g} / \mathrm{m}^{3}$ and $29 \mu \mathrm{g} / \mathrm{m}^{3}$ (6), characterizing the area as a control site for experimental comparisons.

From March 1993 to March 1995 (collections were made every two months) fungi were isolated from the air of five sites chosen in the highly polluted area as well as in the less affected one.

Five Petri dishes with potato-dextrose-agar medium were exposed during five minutes, at one meter of the ground at each site, with a total of 130 Petri dishes during the entire duration of the experiment. In the laboratory the ten dishes were incubated at $20^{\circ} \mathrm{C}$ during five days for purification, and identification of the taxa, based on current literature $(1,2,7,8)$.
Afterwards the strains were included in the Culture Collection of the "Seção de Micologia e Liquenologia" of the "Instituto de Botânica" of the "Secretaria de Estado do Meio Ambiente".

Similarity between the mycota of the sites was established using the index of Sörensen (IS) as follows (18):

$$
\begin{array}{ll}
\text { IS }=\frac{2 \mathrm{C}}{\mathrm{A}+\mathrm{B}} \times 100 & \begin{array}{l}
\text { A: total number of taxa in Moji } \\
\text { B: total number of taxa in Pilões }
\end{array} \\
& \text { C: number of common taxa in both sites }
\end{array}
$$

The frequency of occurrence (18) was calculated for each fungal species:

$\mathrm{F}=\frac{\mathrm{Pa}}{\mathrm{P}} \times 100 \mathrm{~Pa}$ : number of samples containing the taxa $\mathrm{x}$ species
$\mathrm{P}:$ total number of samples

According to the literature (18), the fungal species were considered constant when values for $\mathrm{F}$ were higher than $50 \%$, rare, when lower than $10 \%$, and common when values were situated between 10 and $50 \%$.

\section{RESULTS AND DISCUSSION}

A total of 39 taxa, three unidentified strains of Fusarium and some non-sporulating cultures were obtained during the present study. A total of 28 taxa, one unidentified strain of Fusarium and non-sporulating fungi (71 records) were isolated in the "Vale do Rio Moji" and 29 taxa, two unidentified strains of Fusarium and non-sporulating fungi (72 records) in the "Vale do Rio Pilões". The airborne mycota of the higher polluted site presented 17 common, 12 rare and only one constant fungal species. Three taxa belonged to the Mucorales, one to Ascomycota and the remaining were mitosporic fungi (Table 1).

Ten taxa occurred only in the polluted sites, 11 in the less polluted and 18 occurred in both sites.

Alternaria alternata, Aspergillus candidus, A. restrictus, Cladosporium cladosporioides, and Periconia atropurpurea were isolated exclusively from the air of the polluted sites, while Aspergillus zonatus, A. versicolor, and Nigrospora oryzae were frequent only in the other site.

Comparison of the results presented herein with the literature led to many interesting observations. For instance, the number of genera found here, corresponding to 19 , is considerably lower than those obtained by Purchio et al. (22) more than ten years ago, when 35 genera were obtained in the same region, by exposing 258 Petri dishes, during one year, with weekly samplings. Although traditionally airborne fungi such as Aspergillus, Cladosporium, Epicoccum and Penicillium species were present in the mycota, the most frequent ones were Trichoderma harzianum and T. pseudokoningii, not often mentioned as the most representative ones in other regions. 
Table 1. Fungal occurrences (+) in the Vale do Rio Moji (M-polluted site) and in the Vale do Rio Pilões (P- less polluted) in the region of Cubatão, SP, Brazil, from May/1993 to March/1995, and the frequency of each taxon. Legend: • opportunistic fungi (17); $\square$ associated to plant diseases (21).

\begin{tabular}{|c|c|c|c|c|c|c|c|c|c|c|c|c|c|c|c|}
\hline \multirow{3}{*}{ Fungi $\mathrm{x}$ months } & \multicolumn{5}{|c|}{1993} & \multicolumn{3}{|c|}{1994} & \multicolumn{7}{|c|}{1995} \\
\hline & May & Jul & Sep & Nov & Jan & Mar & May & Jul & Set & Nov & Jan & Mar & Tot & & Freq \\
\hline & M P & M P & M P & M P & M P & M P & M P & M P & M P & M P & M P & M P & & $\mathrm{P}$ & $\mathrm{MP}$ \\
\hline$\square$ Acremonium strictum $\mathrm{W}$. Gams & ++ & + & + & & & & & & + & & & & & & 1733 \\
\hline$\square$ Alternaria alternata (Fr.) Keissler & & & & & & & & & & & & & & & $8-$ \\
\hline Aspergillus brunneo uniseriatus Singh \& Bakshi & & & + & & + & & & & & & & & & & 017 \\
\hline A. candidus Wehmer & + & & & & & & & & & & & & & & \\
\hline$\square$ A. flavus Link & & & & & & & & & ++ & & & & & 1 & 8 \\
\hline$\square$ A. niger van Tieghem & + & + & ++ & & & & + & + & + & & & & & 4 & 3333 \\
\hline$\square$ A. restrictus Smith & & & & & & + & & & & & & & & 0 & 80 \\
\hline$\square$ A. versicolor Tiraboschi & & + & & & & & & & & & + & & 0 & & 017 \\
\hline A. zonatus Kwen \& Fennell & & & & & & & & & + & & & & & 1 & 08 \\
\hline$\square$ Cladosporium oxysporum Berk. \& Curt. & ++ & & ++ & + & & & + & & & & & & & 3 & 2525 \\
\hline$\square$ C. cladosporioides (Fres.) de Vries & & & + & & & + & & + & & + & + & + & 4 & 2 & 3317 \\
\hline 口 Colletotrichum orbiculare (Berk. \& Mont.) Arx & & & & & & & & + & & + & & & 0 & 2 & 017 \\
\hline Cunninghamella blakesleeana Lend. & & & & & & & & + & & & + & & & 1 & 88 \\
\hline$\square$ Curvularia brachyspora Boedijn & & & & & + & & + & & & & + & & 3 & 0 & \\
\hline C. lunata (Wakker) Boedijn & & & + & & & & + & & & & + & + & 3 & 2 & 2517 \\
\hline Drechslera ravenelli (Curt.) Subram. \& Jain. & + & & & & & & & & + & & & + & & 1 & 178 \\
\hline$\square$ Epicoccum nigrum Link & + & & & & & + & & ++ & + & + & & & & 2 & 3317 \\
\hline Fusarium spp. & & & & ++ & & + & & & + & & & & & 2 & 817 \\
\hline$\square$ Fusarium lateritium Nees & & + & & & + & & & & & & & & 0 & 2 & 017 \\
\hline$\square$ F. oxysporum Schlecht. emend Snyd. \& Hans. & ++ & & + & ++ & & & & & + & & ++ & & & 4 & 3333 \\
\hline$\square$ F. sambucinum Fuckel & & & & & & & + & + & & & & & 1 & 2 & 817 \\
\hline $\begin{array}{l}\text { 口 F. solani (Mart.) Appel \& Wollenw. } \\
\text { emend Snyd \& Hans. }\end{array}$ & & & & & & & & & & + & & + & 2 & 0 & \\
\hline $\begin{array}{l}\text { - Mucor hiemalis Wehmer f. corticolus (Hagem) } \\
\text { Schipper }\end{array}$ & & & & & & + & & & & & & & & 0 & 8 \\
\hline $\begin{array}{l}\text { M. hiemalis Wehmer f. luteus (Linnemann) } \\
\text { Schipper }\end{array}$ & & & & & & + & & & & & & & 1 & 0 & \\
\hline Neurospora crassa Shear \& Dodge & & + & & & & & & + & & & & & 2 & 0 & 17 \\
\hline$\square$ Nigrospora oryzae (Berk. \& Br.) Petch & + & & & & & & & & & + & & & & 2 & 017 \\
\hline$\square$ Penicillium aurantiogriseum Dierckx & & & & & & & & & + & & & & 0 & 1 & 08 \\
\hline P. canescens Sopp & & & & + & & & & & + & + & & + & 2 & 2 & 1717 \\
\hline P. echinulatum Raper \& Thom ex Fassatiová & & & & & & & + & & + & & & & & 1 & 8 \\
\hline P. fellutan & & & & & & & + & & & & & & 0 & 1 & 0 \\
\hline P. janthine & & & & & & & & & + & & & & & 1 & 0 \\
\hline P. miczynskii Zaleski & & & & & & + & & & & & ++ & & 2 & 1 & 17 \\
\hline$\square$ P. purpurogenum Stoll & + & & & & + & & & & & & & & & 2 & 017 \\
\hline Periconia atropurpurea (Berk. \& Curt.) Li & + & & & & & & & & & & & & & 0 & 80 \\
\hline$\square$ Pestalotiopsis sp. & & & & & & & & ++ & ++ & ++ & + & + & 5 & 3 & 4225 \\
\hline$\square$ Torula sp. & & & & & & & & & & & & + & & 0 & 80 \\
\hline$\square$ Trichoderma harzianum Rifai & ++ & ++ & ++ & & + & & + & a + & + & + & + & ++ & & 7 & 6758 \\
\hline$\square$ T.pseudokoningii Rifai & & ++ & & ++ & + & ++ & & & + & ++ & + & & & 6 & 4250 \\
\hline$\square$ T. viride Pers. ex Gray sensu Bissett & ++ & & ++ & & & & + & & & & & & 2 & 3 & 1725 \\
\hline$\square$ Zygosporium sp. & + & & & & & & & & + & & & & & 2 & 017 \\
\hline No sporulating fungi & & & & + & & ++ & & + & & & + & & & 1 & 33 \\
\hline Total number of taxa - Moji & $10-$ & $6-$ & $4-$ & $4-$ & 3 & $7-$ & $2-$ & $8-$ & $6-$ & $7-$ & $9-$ & $5-$ & & - & \\
\hline Total number of taxa - Pilões & 9 & \begin{tabular}{|l|}
-6 \\
\end{tabular} & -9 & -4 & $|-3|$ & 4 & -7 & -5 & $\mid-12$ & -5 & $-4 \mid$ & 4 & & 72 & \\
\hline
\end{tabular}


Purchio et al. (22) mentioned high frequencies of Penicillium, Cladosporium, Aspergillus, Epicoccum and Aureobasidium species, but not Trichoderma.

Using the classification pattern of occurrence frequency (18), the following results were obtained: 17 common and 12 rare fungal taxa in the highly polluted region and 20 common besides 9 rare taxa in the other site. Only one species, Trichoderma harzianum, was constant in both sites. Comparison of the results obtained here with other ones available in the Brazilian literature $(4,9,10,11,12,22)$ is impaired because these present lists of fungi identified at genera level. Any assumption will take in consideration this level of information. One will observe the absence of Aureobasidium pullulans frequently mentioned in the Brazilian literature as well as the presence of isolates of Alternaria, absent in the early surveys.

The list of fungi mentioned in Table 1 contains at least 12 taxa reported as opportunistic fungi (17) and 26 have been reported to be associated to plant diseases (21). On the other hand, eight of the genera mentioned have been cited as related to allergy problems $(16,17,20)$.

Regarding the frequency, some species presented differences between the studied sites. For instance, Drechslera ravenelli and Penicillium miczynskii were common in the polluted site, but rare in the less polluted one. On the other hand, Fusarium sambucinum was common in the less polluted site, but rare in the polluted one. How much the polluted air may have influenced the occurrence of these species at the sites remains unknown.

According to Dix and Webster (5) some features of the fungi may contribute to explain their occurrence in polluted sites. For instance, the occurrence of the species of Trichoderma has been linked to the lack of carbon sources, and in the special case of $T$. harzianum, to low content of nitrogen compounds in the soil. Species of Fusarium, particularly F. sambucinum may show a preference for acid soils, justifying their high frequencies in tropical soils, also confirming their important role as primary decomposers in polluted sites.

Non-sporulating fungi were common in the "Vale do Rio Moji", but rare in the "Vale do Rio Pilões" (Table 1), giving some support to the suggestion of Purchio et al. (6) of using non sporulating fungi as indicators of air pollution.

Among the obtained fungi, Alternaria alternata and Epicoccum nigrum were studied to verify the effects of $\mathrm{SO}_{2}$ concentration on spore germination and colony size "in vitro" Their exposure to 0.05 to $0.2 \mathrm{ppm}$ of $\mathrm{SO}_{2}$ for $24 \mathrm{~h}$ at 10 and $20^{\circ} \mathrm{C}$ did not affect their hyphal growth (19). Although A. alternata was once observed, E. nigrum was frequent in the "Vale do Rio Moji", where $\mathrm{SO}_{2}$ concentration is usually high.

The similarity Index of Sörensen between the mycotas, corresponding to $58 \%$, may be considered low, and is probably justified by the air pollution, that mainly distinguish the two studied areas.

\section{ACKNOWLEDGEMENTS}

The authors would like to express their gratitude to the biologists Maria Lúcia dos Santos and Kátia Cristina Giustra for technical help in the field and to Dr. Ramon A. Clark for revision of the English; to CNPq (proc. $n^{\circ}$ 500046/92-1) and FAPESP (proc. $n^{\circ}$ 93/3509-6).

\section{RESUMO}

\section{Fungos anemófilos da região de Cubatão, São Paulo, Brasil}

De março/1993 a março/1995, foram isolados fungos anemófilos no Vale do Rio Moji (afetada pela poluição aérea causada por indústrias de fertilizantes, metalúrgicas, fábricas de cimento e indústrias de produtos químicos, entre outras) e no Vale do Rio Pilões (área menos afetada pela poluição aérea), no município de Cubatão, Estado de São Paulo, Brasil, expondo placas-de-Petri, contendo meio de batata-dextrose-ágar, durante cinco minutos a aproximadamente um metro de altura do solo. Após cinco dias de incubação à $20^{\circ} \mathrm{C}$ as colônias de fungos filamentosos foram purificadas e identificadas, resultando na obtenção de 39 táxons, três isolamentos não identificados de Fusarium e algumas culturas não esporulantes. O total de 28 táxons, um isolado não identificado de Fusarium e fungos não esporulantes (71 registros) foram isolados do Vale do Rio Moji e 29 táxons, dois isolados não identificados de Fusarium e fungos não esporulantes (72 registros) foram obtidos no Vale do Rio Pilões. De acordo com a frequiência de ocorrências dos fungos, na área poluída foram encontradas 17 espécies comuns, 12 raras e uma constante, ao passo que na outra área ocorreram 19 espécies comuns, 10 raras e duas constantes. Entre os fungos obtidos, pelo menos 12 táxons são reportados como fungos oportunistas, 26 associados a doenças de plantas e oito gêneros à problemas alérgicos. $\mathrm{O}$ índice de similaridade de Sörensen entre as micotas, correspondendo a $58 \%$, pode ser considerado baixo, e possivelmente é justificado pela poluição aérea, que distingue principalmente as duas áreas estudadas.

Palavras-chave: diversidade, fungos anemófilos, mata atlântica, poluição aérea

\section{REFERENCES}

1. Barnett, H.L.; Hunter, B.B. Illustrated genera of Imperfect Fungi, $4^{\text {th }}$ Ed, APS Press, Saint Paul, Minn. 1998, 218p.

2. Barron, G.L. The genera of Hyphomycetes from soil. Robert E. Krieger, New York, 1968, 346p.

3. Böhm, G.M.; Saldiva, P.H.N.; Pasqualucci, C.A.; Massad, E.; Martins, M.A.; Zin, W.A.; Cardoso, W.V.; Criado, P.M.P.; Komatsuzaki, M.; Sakae, R.S.; Negri, E.M.; Lemos, M.; Capelozzi, V.M.; Crestana, C.; Silva, R. Biological 
effects of air pollution in São Paulo and Cubatão, p.208-216, 1989 (Annual Report).

4. Buck, N.; Gambale, W. Microbiota fúngica anemófila na cidade de Presidente Prudente, Estado de São Paulo, Brasil. Rev. Microbiol., 16: 9-14, 1985.

5. Dix, N.J.; Webster, J. Fungal Ecology. Cambridge, University Press, 1995, $549 \mathrm{p}$.

6. Domingos, M. Biomonitoramento da fitotoxicidade da poluição aérea e da contaminação do solo na região do polo industrial de Cubatão, São Paulo, utilizando Tibouchina pulchra Cogn como espécie indicadora. São Paulo, 1998, 216p. (Ph.D. Thesis, Instituto de Biociências, USP).

7. Domsch, K.H.; Gams, W.; Anderson, T.H. Compendium of soil fungi. Academic Press, New York, 1980.

8. Ellis, M.B. Dematiaceous Hyphomycetes. Commonwealth Mycological Institute, London, 1971, 608p.

9. Faria, A. Aspectos ecológicos e clínicos da flora micótica anemófila de Belo Horizonte, 1967, 97p. (PhD Thesis, Universidade Federal de Minas Gerais).

10. Gambale, W.; Purchio, A.; Croce, J. Flora fúngica anemófila da grande São Paulo. Rev. Microbiol., 8: 74-79, 1977.

11. Gambale, W.; Purchio, A.; Paula, C.R. Periodicidade diária de fungos anemófilos na cidade de São Paulo, Brasil. Rev. Microbiol., 12: 176-181, 1981.

12. Gambale, W.; Purchio, A.; Paula, C.R. Influência de fatores abióticos na dispersão aérea de fungos na cidade de São Paulo, Brasil. Rev. Microbiol., 14: 204-214, 1983

13. Jaeschke, W. Chemistry module. In: Air pollution and vegetation damage in the tropics. Final Report 1990-1996. Brazilian/German Cooperation in Environmental Research and Technology, Project ENV 3. GKSS Forschungszentrum Geesthacht GmbH. 1997.
14. Klumpp, A.; G. Klump.; Domingos, M. Plants as bioindicators of air pollution at the Serra do Mar near to the industrial complex of Cubatão, Brazil. Environ. Poll., 85: 109-116, 1994.

15. Klumpp, G.; Furlan, C.M.; Domingos, M.; Klumpp, A. Response of stress indicators and growth parameters of Tibouchina pulchra Cogn exposed to air and soil pollution near the insudtrial complex of Cubatão, Brazil. The Science of the Total Environment, 246: 7991, 2000.

16. Lacaz, C.S. Micose e geografia médica. In: Lacaz, C.S.; Baruzzi, R.G.; Siqueira, Jr. W. (eds.). Introdução à geografia médica do Brasil. Edgard Blücher \& EDUSP, São Paulo, 1972, p.368-387.

17. Lacaz, C.S.; Porto, E.; Heins-Vaccari, E.M.; Melo, N.T. Guia de Identificação: fungos, actinomicetos e algas de interesse médico. Ed. Sarvier, São Paulo, 1998.

18. Lobo, E.; Leighton, G. Estruturas de las fitocenosis planctonicas de los sistemas de desembocaduras de rios y estercos de la zona central de Chile. Rev. Biol. Mar., 22: 143-170, 1986.

19. Magan, N.; McLeod, A. R. In vitro growth and germination of phylloplane fungi in atmospheric sulfur dioxide. Trans. Br. mycol. Soc., 90: 571-575, 1988

20. Mendes, E. Processos alérgicos e geografia médica. In: Lacaz, C.S.; Baruzzi, R.G.; Siqueira, Jr. W. (eds.). Introdução à geografia médica do Brasil. Edgard Blücher \& EDUSP, São Paulo, 1972, p.543-568.

21. Mendes, M.A.S.; Silva, V.L.; Dianese, J.C.; Ferreira, M.A.S.V.; Santos, C.E.N.; Neto, E.G.; Urben, A.F.; Castro, C. Fungos em plantas no Brasil. EMBRAPA-CENARGEN, Brasília, 1998.

22. Purchio, A.; Gambale, W.; Paula, C.R.; Ugoline, C.; Remie, C.A. Airborne fungi of Baixada Santista, State of São Paulo, Brazil. Rev. Microbiol., 15:258-265, 1984. 